\title{
Pros and cons of a prion-like pathogenesis in Parkinson's disease
}

\author{
Ruediger Hilker ${ }^{{ }^{*}}$, Jonathan M Brotchie ${ }^{2}$ and Joab Chapman ${ }^{3}$
}

\begin{abstract}
Background: Parkinson's disease (PD) is a slowly progressive neurodegenerative disorder which affects widespread areas of the brainstem, basal ganglia and cerebral cortex. A number of proteins are known to accumulate in parkinsonian brains including ubiquitin and $\alpha$-synuclein. Prion diseases are sporadic, genetic or infectious disorders with various clinical and histopathological features caused by prion proteins as infectious proteinaceous particles transmitting a misfolded protein configuration through brain tissue. The most important form is Creutzfeldt-Jakob disease which is associated with a self-propagating pathological precursor form of the prion protein that is physiologically widely distributed in the central nervous system.
\end{abstract}

Discussion: It has recently been found that $\alpha$-synuclein may behave similarly to the prion precursor and propagate between cells. The post-mortem proof of $\alpha$-synuclein containing Lewy bodies in embryonic dopamine cells transplants in PD patient suggests that the misfolded protein might be transmitted from the diseased host to donor neurons reminiscent of prion behavior. The involvement of the basal ganglia and brainstem in the degenerative process are other congruencies between Parkinson's and Creutzfeldt-Jakob disease. However, a number of issues advise caution before categorizing Parkinson's disease as a prion disorder, because clinical appearance, brain imaging, cerebrospinal fluid and neuropathological findings exhibit fundamental differences between both disease entities. Most of all, infectiousness, a crucial hallmark of prion diseases, has never been observed in PD so far. Moreover, the cellular propagation of the prion protein has not been clearly defined and it is, therefore, difficult to assess the molecular similarities between the two disease entities.

Summary: At the current state of knowledge, the molecular pathways of transmissible pathogenic proteins are not yet fully understood. Their exact involvement in the pathophysiology of prion disorders and neurodegenerative diseases has to be further investigated in order to elucidate a possible overlap between both disease categories that are currently regarded as distinct entities.

\section{Background}

Parkinson's disease (PD) is a sporadic or familial neurodegenerative disorder histopathologically characterized by intraneuronal protein aggregates staining positive for $\alpha$-synuclein (Lewy Bodies, LB). Concomitant Alzheimer disease type neuropathological features with amyloid deposits and plaques are also frequently found [1]. A recent clinico-pathological study on 242 brain donors with pathologically verified PD showed the presence of neurofibrillary tangles in $47 \%$ of cases with non-tremor dominant PD, neocortical amyloid plaque formation in $62 \%$ and amyloid angiopathy in $22 \%$ [2]. Although the

\footnotetext{
* Correspondence: hilker@med.uni-frankfurt.de

'Department of Neurology, Goethe University, Frankfurt/Main, Germany

Full list of author information is available at the end of the article
}

cause of cell death in PD is unknown, the abnormal processing of neuronal proteins seems to play a key role in the pathophysiology of the disease. It has been shown that impaired proteolytic cleavage and degradation of misfolded proteins lead to their intracellular accumulation and conglomeration as LB [3]. One of the key proteins in this process is $\alpha$-synuclein (SNCA). Recent in vitro findings demonstrated that elevated levels of misfolded SNCA can promote its self-aggregation with amyloid formation $[4,5]$. Misfolded SNCA is also able to spread over adjacent neurons and to induce degenerative changes in transfected cells [4]. Moreover, two postmortem studies showed SNCA-positive LB in embryonic dopamine cells of beforehand transplanted PD patients suggesting that the microenvironment of the host brain

Ciomed Central

(c) 2011 Hilker et al; licensee BioMed Central Ltd. This is an Open Access article distributed under the terms of the Creative Commons Attribution License (http://creativecommons.org/licenses/by/2.0), which permits unrestricted use, distribution, and reproduction in any medium, provided the original work is properly cited. 
is able to induce abnormal protein aggregation in the transplants [6,7]. Therefore, the debate came up whether SNCA behaves like a prion protein and PD might be a prion-like disease [8], which opens up an exciting new perspective on the pathomechanisms of neurodegenerative diseases in general. However, it has to be kept in mind that PD is neither infectious nor has it been transmitted to laboratory animals. The aim of this paper is to summarize important pros and cons of the prion hypothesis of PD.

\section{Discussion}

\section{Molecular biology of prion diseases}

Prion proteins $(\mathrm{PrP})$ are infectious proteinaceous particles devoid of nucleic acids causing animal and human brain diseases by transmitting a misfolded protein configuration through brain tissue [9]. The cellular prion protein $\left(\mathrm{PrP}^{\mathrm{C}}\right)$ is the endogenous and physiological form with a predominant $\alpha$-helix structure, which can be found on cell membranes of many tissues. In contrast, the prion protein scrapie $\left(\mathrm{PrP}^{\mathrm{Sc}}\right)$ isoform, which is encoded by the chromosomal prion protein gene (PRNP), is an infectious agent with a much higher proportion of $\beta$-sheet structure and a strong tendency to aggregate in form of amyloid fibers and plaques [10]. $\mathrm{PrP}^{\mathrm{Sc}}$ is able to convert normal $\operatorname{PrP}^{\mathrm{c}}$ into the infectious $\mathrm{PrP}^{\mathrm{Sc}}$ by a conformation change from $\alpha$-helix to $\beta$-sheet structure, which is considered the key event underlying prion diseases [9]. In this scenario, $\mathrm{PrP}^{\mathrm{Sc}}$ acts like a template for the conversion of $\operatorname{PrP}^{\mathrm{C}}$ into nascent $\operatorname{PrP}^{\mathrm{Sc}}$ constituting a self-propagating vicious cycle [11]. Prion diseases can be basically caused by three pathogenic mechanisms: 1 . sporadic configuration change from $\operatorname{PrP}^{\mathrm{c}}$ to $\mathrm{PrP}^{\mathrm{Sc}}, 2$. genetic origin by mutations in the PRNP gene and 3. transfection of $\operatorname{PrP}^{\mathrm{Sc}}$ and subsequent conversion of $\operatorname{PrP}^{\mathrm{c}}$ by the ingested pathogen. The accumulation and limited proteolysis of $\operatorname{PrP}^{\mathrm{Sc}}$ leads to the small molecule PrP27-30 which polymerizes into amyloid potentially capable of inducing neurodegenerative changes in brain tissue [12]. Prion diseases manifest as sporadic, genetic or infectious disorders with a variety of clinical symptoms and histopathological findings. The most common form is sporadic Creutzfeld-Jakob disease (CJD) with an incidence of nearly 5 per 1 million among individual between 60 and 74 years of age [13]. CJD is histopathologically characterized by spongiform brain degeneration and astrogliosis with amyloid plaques and positive antibody staining against $\mathrm{PrP}^{\mathrm{Sc}}$ in about 10 percent of cases $[14,15]$.

\section{Molecular biology of alpha-synuclein (SNCA)}

Several lines of evidence point to the outstanding importance of SNCA for PD pathophysiology. SNCA has been shown to be a major component of $\mathrm{LB}$ as the pathological hallmark of PD patients containing characteristic protein aggregates in widespread brain areas $[16,17]$. Mutations of the SNCA encoding gene are associated with familial forms of PD [18]. Increased intracellular SNCA levels can arise from duplication or triplication of the wild-type protein in familial cases $[19,20]$ or from impaired lysosomal and proteasomal clearance of the protein in sporadic PD [21]. Moreover, previous data documented neuronal degeneration by the inhibition of proteasomal protein degradation and subsequent inclusion formation [22]. Other potentially toxic effects of SNCA are the induction of endoplasmatic reticulum stress, sequestration of anti-apoptotic proteins and the formation of pores in cellular membranes [23].

\section{Arguments for a prion-like pathogenesis in PD}

The prion-like disease hypothesis of PD is particularly based upon striking parallels in the biological properties and behavior of $\mathrm{PrP}^{\mathrm{Sc}}$ and SNCA. The first one is that both have

$\alpha$-helical rich conformation when bound to membranes and that both undergo a change to $\beta$-sheet structure polymerizing into amyloid fibrils when present in high concentration or in mutant form $[24,25]$. The second important similarity is that misfolded SNCA also promotes a self-propagating conformation change of its physiological alpha-helical isomer leading to potentially toxic protein accumulation and to interference with lysosome and proteasome function [5]. The third important parallel between SNCA and $\operatorname{PrP}^{\mathrm{Sc}}$ is that both reveal a kind of transmissibility. While the infectious nature of spongiform encephalopathies is undoubtedly proven, a recent pathbreaking study demonstrated that SNCA can be directly transferred from SNCA overexpressing neurons to adjacent healthy stem cells in transgenic animals with the subsequent development of inclusion bodies and signs of neuronal degeneration [4]. Direct cell-to-cell propagation of SNCA was mediated by endocytosis of recipient cells. SNCA accumulated when lysosomes in recipient cells were inhibited. The donor-derived SNCA formed juxta-nuclear inclusion bodies and recipient cells showed signs of apoptosis (nuclear fragmentation, caspase-3 activation). A further line of evidence comes from two recent post-mortem studies showing SNCA-positive LB in embryonic dopamine cells of PD patients who had been transplanted over ten years ago $[6,7]$. Since the appearance of LB has never been described in embryonic neurons before, it is very likely that the microenvironment of the diseased host brain led to the development of SNCA-positive aggregates in the transplants. One possible explanation for this finding is that misfolded SNCA is transmitted from the affected host to primarily healthy donor neurons inducing the fatal chain reaction of further protein misfolding. 
Recently, the staging hypothesis of PD proposed by Braak and colleagues has attracted enormous attention [26]. It assumes that a currently unknown pathogen enters the central nervous system via the olfactory epithelium and enteric nerves and reaches the olfactory bulb and the dorsal motor nucleus of the vagal nerve via antero- and retrograde transport. In later disease stages, the process spreads in a sequential ascending manner particularly in neurons rich of native SNCA, such as the enthorhinal cortex, hippocampus, amygdala, substantia nigra, insula and temporo-basal cortex. The hypothesis that misfolded SNCA acts like a prion with sequential cell-to-cell transmission offers an attractive explanation of Braak's findings. These are indeed compatible with the view of $P D$ as a prion-like disorder resulting from increased production or insufficient degradation of toxic SNCA. In this scenario, the abnormal conversion of native to $\beta$-sheet SNCA might be triggered or supported by various drivers, such as hereditary factors, aging, oxidative stress or environmental toxins.

Finally, the similarity of genetic forms of PD and prion diseases is noticeable. The inherited forms of prion diseases base on different mutations in the prion protein gene (PRNP) on chromosome 20, which are associated with various clinical phenotypes and responsible for about $10-15 \%$ of prion disorders [27]. At the protein level, the encoded mutated PrPs seem to fold into different pathogenic conformers accounting for the phenotypic variability [28]. The E200K mutation is the most prevalent one worldwide with autosomal-dominant inheritance and incomplete penetrance leading to a genetic form of CJD with rapidly progressive dementia and myoclonus along with pyramidal, cerebellar and extrapyramidal signs [29]. Just like prion disease, most PD cases are sporadic, but also several inherited monogenetic PD forms were identified over the last decade [30]. The first reported were autosomal-dominant mutations of the SNCA gene on the long arm of chromosome 4 (PARK1) [18]. Similar to mutated PrPs, aminoacid changes in the SNCA encoded protein presumably leads to an increased tendency for intracellular aggregate formation [31]. Multiplications of the wildtype SNCA gene have been shown to induce higher SNCA blood levels [32] and to cause familial parkinsonism [20]. Although the exact physiological properties of wild-type SNCA and PrP are not yet completely understood, a gain-of-function of the mutated protein with certain importance for the neurodegenerative process in PD and in prion diseases is likely in both (see $[33,34]$ for detailed reviews). Transgenic (PG14-EGFP) mice develop an ataxic neurological disease with aggregation of a partially protease-resistant mutant PrP [35]. A similar disease process has been demonstrated in mouse prion promoter $(\mathrm{mPrP}) \mathrm{A} 53 \mathrm{~T}$ SNCA transgenic mice, which revealed SNCA aggregation and progressive agedependent neurodegeneration [36,37].

\section{Arguments against a prion-like pathogenesis in PD}

CJD is a rapidly progressive disease associated with a self-propagating pathological prion protein. The life cycle of a prion includes synthesis in the endoplasmic reticulum of many cell types in- and outside the brain, transport to the external cellular membrane, secretion and trans-synaptic transport to neighbouring neurons and astrocytes, re-entry into the cell and degredation in the lysosomal apparatus. Prion proteins travel large distances systemically in the blood stream carried by lymphocytes and through the central nervous system along axons that can be more than one meter in length [38]. Concerning neuropathological similiarities between CJD and $\mathrm{PD}$, it is important to consider which specific features of prion replication are actually mimicked by SNCA.

Many disease processes, such as Alzheimer's and Huntington disease, cerebellar ataxias or serpinopathies, include the accumulation of a pathological protein, an initiation "seed" of protein aggregation, stable protein aggregates, diffusion of the pathological protein and the potential for the pathological protein to cause cell damage leading in turn to enhanced protein accumulation. It is not absolutely clear how SNCA directly causes propagation of its abnormal form. As in prion pathology, it has been hypothesized that a direct interaction exists between the pathological beta pleated sheet and the normal alpha coil form leading the latter to be transformed into pathological aggregates [8]. However, even in the classical PrP associated prion diseases the exact mechanism of propagation has not been clearly defined or replicated under physiological cell free conditions. In addition, prion accumulation in cell cultures does not seem to have the same detrimental effects, for example apoptosis, which can be observed in cultures exposed to pathological SNCA. Therefore, it is currently hardly to argue that these processes are significantly similar.

From a clinical point of view, CJD and PD are very different diseases. While PD has a slow but continuously progressive course, CJD remains latent for many years followed by a rapid and exponentially devastating phase that ends within a few months. Typical clinical manifestations of CJD, such as early occurring dementia, ataxia and myoclonus, are usually not found in PD. CJD patients have typical EEG findings, for example triphasic waves or periodic lateralized epileptic discharges, and a characteristic increase of tau and 14-3-3 protein in the CSF, which are absent in PD. A recent cross-sectional study in patients with various neurodegenerative diseases has performed direct ELISA quantification of 
SNCA in the CSF [39]. The mean SNCA values were significantly lower in donors with a primary synucleinopathy (PD, Dementia with Lewy Bodies) than in the other study subgroups, whereas CJD patients showed markedly elevated SNCA levels. Magnetic resonance imaging often reveals hyperintense lesions in the basal ganglia and the thalamus of CJD patients, which are lacking in PD. Furthermore, spongiform encephalopathy as the pathological hallmark of CJD is not a feature of $\mathrm{PD}$, whereas LB are not present in CJD. Infectiousness is a crucial hallmark of prion diseases, which can manifest after iatrogenic procedures such as neurosurgical operations as well as corneal and dural transplantations [40], whereas this kind of transmission has never been documented in PD patients so far. Finally, disease modifying substances have been found in PD animal models in vitro, while no such agents are currently available for CJD.

\section{Summary}

The prion-like hypothesis of PD implies a redefinition of the term prion away from its exclusive use in transmissible spongiform encephalopathies towards a general infectious principle in protein misfolding and aggregation diseases. It focuses the researchers' attention on the key role of SNCA malfunction in the pathogenesis of PD and implies that blocking the mishandling of SNCA and other proteins might be an effective therapeutic strategy in PD patients. However, at the current state of knowledge, a number of issues advise caution before categorizing PD as a prion disorder, because the molecular pathways of transmissible pathogenic proteins are not yet fully understood and clinical, brain imaging, CSF and neuropathological findings clearly differ in patients with classic prion diseases and PD.

\section{Acknowledgements and funding}

This manuscript summarizes the debate "Does PD have a prion-like pathogenesis?" on the $3^{\text {rd }}$ World Congress on Controversies in Neurology (CONy) held on October 8-11 2009 in Prague. We thank Prof. Amos D. Korczyn for his support.

\section{Author details \\ 'Department of Neurology, Goethe University, Frankfurt/Main, Germany. ${ }^{2}$ Toronto Western Research Institute, Toronto Western Hospital, Toronto, Canada. ${ }^{3}$ Department of Neurology, Sheba Medical Center, Tel Aviv University, Sackler Faculty of Medicine, Israel.}

\section{Authors' contributions}

All authors participated on the debate during the $3^{\text {rd }}$ World Congress on Controversies in Neurology (CONy) held on October 8-11 2009 in Prague and prepared, read and approved the final manuscript. RH primarily drafted had the background section and the pro arguments in the discussion, JC primarily drafted the cons, and JMB had particular responsibility for the conclusions in the summary.

\section{Competing interests}

The authors declare that they have no competing interests.
Received: 28 February 2011 Accepted: 20 June 2011

Published: 20 June 2011

\section{References}

1. Jellinger KA: Neuropathological aspects of alzheimer disease, parkinson disease and frontotemporal dementia. Neurodegener Dis 2008, 5:118-121.

2. Selikhova M, Williams DR, Kempster PA, Holton UL, Revesz T, Lees AJ: A clinico-pathological study of subtypes in parkinson's disease. Brain 2009, 132:2947-2957.

3. McNaught KS, Olanow CW, Halliwell B, Isacson O, Jenner P: Failure of the ubiquitin-proteasome system in parkinson's disease. Nat Rev Neurosci 2001, 2:589-594.

4. Desplats P, Lee HJ, Bae EJ, Patrick C, Rockenstein E, Crews L, Spencer B, Masliah $E$, Lee $S J$ : Inclusion formation and neuronal cell death through neuron-to-neuron transmission of alpha-synuclein. Proc Natl Acad Sci USA 2009, 106:13010-13015.

5. Snyder H, Mensah K, Theisler C, Lee J, Matouschek A, Wolozin B: Aggregated and monomeric alpha-synuclein bind to the $56^{\prime}$ proteasomal protein and inhibit proteasomal function. J Biol Chem 2003, 278:11753-11759.

6. Kordower JH, Chu Y, Hauser RA, Freeman TB, Olanow CW: Lewy body-like pathology in long-term embryonic nigral transplants in parkinson's disease. Nat Med 2008, 14:504-506.

7. Li JY, Englund E, Holton JL, Soulet D, Hagell P, Lees AJ, Lashley T, Quinn NP, Rehncrona S, Bjorklund A, Widner H, Revesz T, Lindvall O, Brundin P: Lewy bodies in grafted neurons in subjects with parkinson's disease suggest host-to-graft disease propagation. Nat Med 2008, 14:501-503.

8. Olanow CW, Prusiner SB: Is parkinson's disease a prion disorder? Proc Natl Acad Sci USA 2009, 106:12571-12572.

9. Prusiner SB: Prions. Proc Natl Acad Sci USA 1998, 95:13363-13383.

10. Pan KM, Baldwin M, Nguyen J, Gasset M, Serban A, Groth D, Mehlhorn I, Huang Z, Fletterick RJ, Cohen FE, et al: Conversion of alpha-helices into beta-sheets features in the formation of the scrapie prion proteins. Proc Natl Acad Sci USA 1993, 90:10962-10966.

11. Prusiner SB: Shattuck lecture-neurodegenerative diseases and prions. $N$ Engl J Med 2001, 344:1516-1526.

12. McKinley MP, Meyer RK, Kenaga L, Rahbar F, Cotter R, Serban A, Prusiner SB: Scrapie prion rod formation in vitro requires both detergent extraction and limited proteolysis. J Virol 1991, 65:1340-1351.

13. Holman RC, Khan AS, Belay ED, Schonberger LB: Creutzfeldt-jakob disease in the united states, 1979-1994: Using national mortality data to assess the possible occurrence of variant cases. Emerg Infect Dis 1996, 2:333-337.

14. DeArmond SJ, Ironside WJ: Neuropathology of prion diseases. In Prion biology and diseases. Edited by: Prusiner SB. Cold Spring Harbor, N.Y: Cold Spring Harbor Laboratory Press; 1999:585-652.

15. DeArmond SJ, McKinley MP, Barry RA, Braunfeld MB, McColloch JR, Prusiner SB: Identification of prion amyloid filaments in scrapie-infected brain. Cell 1985, 41:221-235.

16. Spillantini MG, Crowther RA, Jakes R, Hasegawa M, Goedert M: Alphasynuclein in filamentous inclusions of lewy bodies from parkinson's disease and dementia with lewy bodies. Proc Natl Acad Sci USA 1998, 95:6469-6473.

17. Spillantini MG, Schmidt ML, Lee VM, Trojanowski JQ, Jakes R, Goedert M: Alpha-synuclein in lewy bodies. Nature 1997, 388:839-840.

18. Polymeropoulos MH, Lavedan C, Leroy E, Ide SE, Dehejia A, Dutra A, Pike B, Root H, Rubenstein J, Boyer R, Stenroos ES, Chandrasekharappa S, Athanassiadou A, Papapetropoulos T, Johnson WG, Lazzarini AM, Duvoisin RC, Di lorio G, Golbe LI, Nussbaum RL: Mutation in the alphasynuclein gene identified in families with parkinson's disease. Science 1997, 276:2045-2047.

19. Chartier-Harlin MC, Kachergus J, Roumier C, Mouroux V, Douay X, Lincoln S, Levecque C, Larvor L, Andrieux J, Hulihan M, Waucquier N, Defebvre L, Amouyel P, Farrer M, Destee A: Alpha-synuclein locus duplication as a cause of familial parkinson's disease. Lancet 2004, 364:1167-1169.

20. Singleton $A B$, Farrer $M$, Johnson J, Singleton A, Hague $S$, Kachergus J, Hulihan M, Peuralinna T, Dutra A, Nussbaum R, Lincoln S, Crawley A, Hanson M, Maraganore D, Adler C, Cookson MR, Muenter M, Baptista M, Miller D, Blancato J, Hardy J, Gwinn-Hardy K: Alpha-synuclein locus triplication causes parkinson's disease. Science 2003, 302:841. 
21. Chu Y, Dodiya H, Aebischer P, Olanow CW, Kordower JH: Alterations in lysosomal and proteasomal markers in parkinson's disease: Relationship to alpha-synuclein inclusions. Neurobiol Dis 2009, 35:385-398.

22. Rideout HJ, Larsen KE, Sulzer D, Stefanis L: Proteasomal inhibition leads to formation of ubiquitin/alpha-synuclein-immunoreactive inclusions in pc12 cells. J Neurochem 2001, 78:899-908.

23. Cookson MR, van der Brug M: Cell systems and the toxic mechanism(s) of alpha-synuclein. Exp Neurol 2008, 209:5-11.

24. Conway KA, Harper JD, Lansbury PT: Accelerated in vitro fibril formation by a mutant alpha-synuclein linked to early-onset parkinson disease. Nat Med 1998, 4:1318-1320.

25. Ferreon AC, Gambin Y, Lemke EA, Deniz AA: Interplay of alpha-synuclein binding and conformational switching probed by single-molecule fluorescence. Proc Natl Acad Sci USA 2009, 106:5645-5650.

26. Braak H, Del Tredici K, Rub U, de Vos RA, Jansen Steur EN, Braak E: Staging of brain pathology related to sporadic parkinson's disease. Neurobiol Aging 2003, 24:197-211.

27. Windl O, Giese A, Schulz-Schaeffer W, Zerr I, Skworc K, Arendt S, Oberdieck C, Bodemer M, Poser S, Kretzschmar HA: Molecular genetics of human prion diseases in germany. Hum Genet 1999, 105:244-252.

28. Piccardo P, Dlouhy SR, Lievens PM, Young K, Bird TD, Nochlin D, Dickson DW, Vinters HV, Zimmerman TR, Mackenzie IR, Kish SJ, Ang LC, De Carli C, Pocchiari M, Brown P, Gibbs CJ Jr, Gajdusek DC, Bugiani O, Ironside J, Tagliavini F, Ghetti B: Phenotypic variability of gerstmannstraussler-scheinker disease is associated with prion protein heterogeneity. J Neuropathol Exp Neurol 1998, 57:979-988.

29. Mead S: Prion disease genetics. Eur J Hum Genet 2006, 14:273-281.

30. Gasser T: Update on the genetics of parkinson's disease. Mov Disord 2007, 22:S343-S350.

31. Goedert M, Spillantini MG, Davies SW: Filamentous nerve cell inclusions in neurodegenerative diseases. Curr Opin Neurobiol 1998, 8:619-632.

32. Miller DW, Hague SM, Clarimon J, Baptista M, Gwinn-Hardy K, Cookson MR, Singleton $A B$ : Alpha-synuclein in blood and brain from familial parkinson disease with snca locus triplication. Neurology 2004, 62:1835-1838.

33. Dawson TM, Ko HS, Dawson VL: Genetic animal models of parkinson's disease. Neuron 2010, 66:646-661.

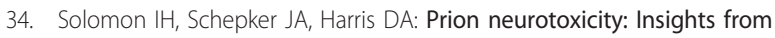
prion protein mutants. Curr Issues Mol Biol 2010, 12:51-61.

35. Medrano AZ, Barmada SJ, Biasini E, Harris DA: Gfp-tagged mutant prion protein forms intra-axonal aggregates in transgenic mice. Neurobiol Dis 2008, 31:20-32.

36. Chesselet MF: In vivo alpha-synuclein overexpression in rodents: A useful model of parkinson's disease? Exp Neurol 2008, 209:22-27.

37. Chesselet MF, Fleming S, Mortazavi F, Meurers B: Strengths and limitations of genetic mouse models of parkinson's disease. Parkinsonism Relat Disord 2008, 14(Suppl 2):S84-87.

38. Fournier JG: Cellular prion protein electron microscopy: Attempts/limits and clues to a synaptic trait. Implications in neurodegeneration process. Cell Tissue Res 2008, 332:1-11.

39. Mollenhauer B, Cullen V, Kahn I, Krastins B, Outeiro TF, Pepivani I, Ng J, Schulz-Schaeffer W, Kretzschmar HA, McLean PJ, Trenkwalder C, Sarracino DA, Vonsattel JP, Locascio JJ, El-Agnaf OM, Schlossmacher MG: Direct quantification of csf alpha-synuclein by elisa and first crosssectional study in patients with neurodegeneration. Exp Neurol 2008, 213:315-325.

40. Brown K, Mastrianni JA: The prion diseases. J Geriatr Psychiatry Neurol 2010, 23:277-298.

\section{Pre-publication history}

The pre-publication history for this paper can be accessed here: http://www.biomedcentral.com/1471-2377/11/74/prepub

doi:10.1186/1471-2377-11-74

Cite this article as: Hilker et al:: Pros and cons of a prion-like pathogenesis in Parkinson's disease. BMC Neurology 2011 11:74.

\section{Submit your next manuscript to BioMed Central and take full advantage of:}

- Convenient online submission

- Thorough peer review

- No space constraints or color figure charges

- Immediate publication on acceptance

- Inclusion in PubMed, CAS, Scopus and Google Scholar

- Research which is freely available for redistribution

Submit your manuscript at www.biomedcentral.com/submit
Biomed Central 